\title{
REDUCE THE RISK OF STOCK TRADING BY USING TECHNICAL ANALYSIS IN IRAN'S STOCK MARKET
}

\author{
M. Sokhanvar ${ }^{*}$, A. Farman
}

Department of Economic Sciences, Urmia Branch, Islamic Azad University, Urmia, Iran

Published online: 16 July 2016

\begin{abstract}
One of the basic criteria for evaluating the performance of a stock portfolio is taking into account the return on investment with the rate of their risk. In this research, efficiency of 50 active companies of Tehran Stock Exchangeevaluated by moving average method with their appropriate risk. In measuring mentioned strategic risk, Fama and French three-factor developed model has been used toughlywhich is among the most important models. The results indicate significant effects of excess market efficiency, size of company and the ratio of book value to market value.In other words, the risk premium of price, size and value of market was predicted which with increasing the efficiency of stock in proportion to efficiency of government bonds, market efficiency also increase.And the risk premium of size and value has negative impact on efficiency of stock forecasting. With this observation, this research suggest forming a portfolio with zero cost by purchasing the highest portfolio of book value at market prices (BM) and selling lowest portfolio of book value at market prices (BM) by signals issued by Moving Average.
\end{abstract}

Keywords: technical analysis, efficiency, risk, moving averages, Fama and French

Author Correspondence, e-mail: m.sokhanvar2010@gmail.com

doi: http://dx.doi.org/10.4314/jfas.v8i2s.28

\section{INTRODUCTION}

Stock exchange always has been interested by investors whether as a field of merchants and traders or as a suitable place to invest. But the question has been raised for newcomers to this area that activists and professionals decide in this market to reduce the risk and discover that 
to know, using which methods and approaches of predicting the stock exchange can provide better profitability?

All stock trades are inherently risky.People in the stock market are always looking for risk measurement to get optimal investment decisions. They are always trying to maximize risk premium of their own investment.Investors in the stock, for reducing unsystematic Riskof investment, attempted to form Investment Portfolio with any types that diversification will be able to reduce unsystematic risk.

Also study further investigations prove that technical analysis can turn a loser investor into a winner investor and also reach winning investor to a higher level of benefits. In technical analysis, it is believed that current price has all information about a stock and movement of the price is not random, because in this method, price is result of the war between the forces of supply and demand.

In this regard, Fama and French stated a foundation for an index based on the characteristics of the business model in a series of articles in late 1990. They found that both size and the ratio of the book value of stock to their market value have a strong role in determining the average efficiency of common stock in the cross sections. They also found that small firms and firms that have a lower book value tomarket value are riskier than other firms.

\section{Theoretical foundations and background of the research}

Brown and Jennings (1989), Brock, Lakonishok and Baron (1992), Lu, Mamayskay, and Wang (2000), And Nili, Rapach,tuo, and Jiu (2011) all found that technical analysis increases market efficiency or the value of stock investment.

InTaiwan stock exchange, Cowan et al. (2013) confirmed that a professional investor can earn higher efficiency with the help of some technical analysis such as the use of moving average method and by calculating the book value of market price (BM) and consideration of purchase and maintenance strategy.

Han, Yang, and Jiu (2013) showed that the use of ruling of moving average (MA) for classified portfolios can swing higher efficiency and return is most reliable than traditional purchase and maintenance strategy.

By examining 25 cases of emerging countries, Rowan Hurst (1999) found that in 11 countries stock with the book value of high market price has higher efficiency in comparing to stock with the book value of low market price. Also for Asian markets, Mukerji et al. (1997), Chen and Zhang (1998), Choi and Vey (1998), and Ding, Choa, and Featherstone (2005)Show that stock with the book value of high market price is the best growth stocks in Japan, Hong Kong, Korea, Malaysia and Singapore,but not in Indonesia, Taiwan and Thailand. 
Coeur et al. (2008) investigated the effect of information risk that caused by Quality of accrual items on risk premium of investment portfolios. They concluded that the time-series regression was performed in research of Francis et al. (2005) did not provide necessary evidence for proofing that the quality of accrual items is an information risk factor. Then they use a two-step cross-sectional regression of Fama and Macbeth (1973) toexamine the effect of accrual items quality on risk premium of investment portfolios. Hereby assess the related risk information.By using this test, they did not achieve any evidence that quality accrual item is risk factor in information related to efficiency.

The only common case among the studies, which shows a buy and hold strategy is by creating annual balancing, is the approach that provided by Fama and French (1992). Fama and French $(1992,1996)$ showed that the value premium is a common phenomenon in the United States market. Fama and French research (1998) also indicates the presence of premium value in a specific country outside the United States or as a whole in throughout the United States.

Ahmadpur and Rasaiian (2006), with using information related to about 156 sample companies during the years 2002 to 2004,evaluated the relationship between risk measures andthe differences in suggested price of buying and selling stock in Tehran Stock Exchange. Results of this study showed that the correlation coefficient is negative between variable of suggested price differences of buying and selling stock with other variables such as the number of transaction in each day, the percentage of days doing business, daily turnover of company stock, market value, and percent of interest payments, size and growth of property. In addition, the results showed that the correlation coefficient is positivebetween variable of suggested price differences of buying and selling stock with other accounting risk measures such as leverage, liquidity and profit variability and market risk criteria like beta and variability of price and also Rial volume of daily trading stock.

Considering the importance of the relationship between risk and efficiency, Yahyazadehfar and Khorramdin (2008) studied the impact of illiquidity risk and liquidity factors such as excess market efficiency, size and the ratio of book value to market value, on the excess efficiency of stock.In this study, they used a time series model for the period from April 1999 to March 2005 each month in Tehran Stock Exchange and all the companies listed in the Stock Exchange are includedwhich their shares have been traded in stock at least 100 days over 9 months. The results show that the impact of illiquidity and the size of the company's share efficiency are negative,but the effect of book value to market value on excess of efficiency of stock is positive. 
It should be noted that three-factor of Fama and French model in Tehran Stock Exchange has been tested in several studies.For example, The results of Aghabeighi (2005), Robat Karimi (2007), Taremi(2007), And Ahmad Mokarem (2007) confirmed the three-factor of Fama and French model in predicting stock efficiency in Tehran Stock Exchange. Also in research of Makarem (2007), the relationship between firm sizes, with stock efficiency was negative and the relationship between the ratio of book value to market value of stock and stock efficiency were positive.Bagherzadeh (2005) appropriates a model that consists both size and ratio of book value to market value at Tehran Stock Exchange.

\section{METHODOLOGY AND RESEARCH TOOLS}

This research is the field Ex-Post Factoresearch.The main purpose of Ex-Post Facto is reviewing the cause and effect relationships by studying the existing results and previous background work that is done in the hope of finding the reason. In this study, statistically valid information that related to the past has been used.In this respect, 50 companies listed in Tehran Stock Exchange are considered in the period from 2008 to 2014 that selection criteria of these companies are non-closed symbols in the base year and the high number of trading days during the period of study.

Information, documents, statistics, stock records, prices available to them that was published by studying newspapers and magazines, CDs, has been extracted by exchange organization,financial data processing centerof the Iranian main sites $^{1}$, development and Islamic studies ${ }^{2}$, Tehran Securities Exchange Technology Management Company ${ }^{3}$, Tehran Stock Exchange ${ }^{4}$, Iranian OTC ${ }^{5}$, Kodal Comprehensive system ${ }^{6}$, and the Tehran Stock Exchange $^{7}$, and other related services sites such as center of Iranian investment institutions site and site of Central Depository of stocks company and settlement of funds and ....

Required data for measuring research variables were measured through software MofidTrader 5 and Amibroker and these data were then entered into Excel software. SPSS and EViews 8 software was used for statistical analysis and finally compared and conclusions are conducted based on each of the purchase and maintenance strategies and moving averages.

\footnotetext{
${ }^{1}$ http://www.fipiran.com/

${ }^{2}$ http://rdis.ir/

${ }^{3}$ http://www.tsetmc.com/

${ }^{4}$ http://www.seo.ir/

${ }^{5}$ http://www.ifb.ir/

${ }^{6}$ http://www.codal.ir/

${ }^{7}$ http://new.tse.ir/
} 


\section{Assumptions and variables of the study and method of calculating them}

Assumptions considered in this research are as follows: The average of buy-and-maintenance portfolio efficiency in short term of one year is more than moving average method. The average of buy-and-maintenance portfolio efficiency is more than average efficiency of moving average method portfolio.The average efficiency of portfolios of short-term and longterm of buy-and-maintenance method has significant differences. There is a significant relationship between stock efficiency and efficiency of bonds.Also in this study, price volatility and stock returns have been used as research variables and calculated by using the following equation.

\section{Determining the average of efficiency in normal mode}

Calculation of stock efficiency in normal mode was through the following method.

(1) $r i, t_{+1}=\operatorname{Ln}(P i, t+1)-\operatorname{Ln}(P i, t)$

Where $r i, t_{+1}$ is the rate of efficiency of share $\mathrm{i}$ in period of $\mathrm{t}$; $L n$ is natural logarithm, $P i, t+1$ is share price of $i$ at the end of period of $t$; The share price $i$ at the beginning of period $t$.

\section{Determining the average of efficiency in the case of bonus shares}

Calculation of stock efficiency, when profit contributed was through the following method.

(2) $r i, t+1=\operatorname{Ln}\lfloor P i, t(1+y) P i, t+1 /(P i, t+100 \times y\rfloor-\operatorname{Ln}(P i, t)$

Where $r i i_{+1}$ is the rate of efficiency of share $i$ in period of $t$; $L n$ is natural logarithm, $P i, t+1$ is share price of $i$ at the end of period of $t$; The share price $i$ at the beginning of period $t$. $y$ Percent of increased investment from cash and demands and the number 100 is amount of payment of each share i for increasing investment from earns cash.

\section{Calculated the efficiency based on the moving average method}

In this method, if the sign of buying for each shareis created based on Moving Average rule, that shares purchased and efficiency of them is calculated and if there was a sale sign, the desired shares sold and its money has been invested in bonds. The method of calculating stock efficiency based on the moving averages as follows:

(3) $R \mathrm{si}=\sum_{t=0}^{N-1} d_{t+1} r_{i, t+1}+(1-\mathrm{dt}+1) \times r_{f, t+1}$

\section{Calculation of efficiency based on Fama and French method}

The results of Fama and French study (1993) shows that from two dimensions of regression analysis (On the one hand, the significance of slope and,the high R2 and on the other hand the intercept in regression), three factors of stock risk can explain efficiency well. Threefactor model that was tested is as follows:

(4) $\mathrm{R}(\mathrm{t})-\mathrm{RF}(\mathrm{t})=\mathrm{a}+\mathrm{b}[\mathrm{RM}(\mathrm{t})-\mathrm{RF}(\mathrm{t})]+\mathrm{sSMB}(\mathrm{t})+\mathrm{hHML}(\mathrm{t})+\mathrm{e}(\mathrm{t})$ 
$\mathrm{SMB}^{1}$ is the difference of big and small stock portfolio efficiency (On the basis of the market value):

(5) $S M B=\frac{\left(\frac{S}{L}+\frac{S}{M}+\frac{S}{H}\right.}{3}-\frac{\left(\frac{B}{L}+\frac{B}{M}+\frac{B}{H}\right.}{3}$

$\mathrm{HML}^{2}$ is the difference between the efficiency of valuable portfolio and growth portfolios (Premium value):

(6) $H M L=\frac{\left(\frac{S}{H}+\frac{B}{H}\right)}{2}-\frac{\left(\frac{S}{L}+\frac{B}{L}\right)}{2}$

$\mathrm{b}[\mathrm{RM}(\mathrm{t})-\mathrm{RF}(\mathrm{t})]$ is market risk premium in year $\mathrm{t}$, that is shown with MKT in the regression formula provided by Fama and French. (The difference between the market efficiency and risk-free efficiency (according to Central Bank statistics, interest rates on account of Bondsextracted as Table 1 and acted upon it.

Table 1. Rate of Bonds efficiency, according to the Central Bank of Iran

\begin{tabular}{|c|c|c|c|c|c|c|c|}
\hline Year & 2008 & 2009 & 2010 & 2011 & 2012 & 2013 & 2014 \\
\hline $\begin{array}{c}\text { Rate of } \\
\text { efficiency }\end{array}$ & $12 \%$ & $12 \%$ & $14 \%$ & $15 \%$ & $15 \%$ & $15 \%$ & $22 \%$ \\
\hline
\end{tabular}

Fama and French (1992) also concluded that adding two risk factors of bonds did not have any effect on the above regression slope coefficient of determination (R2) and the intercept.

\section{RESULTS OF RESEARCH:}

In order to classify the shares of sample companies during the estimation, first ratio of book value $^{3}$ to market value (BM) of companies stock in the sample, calculated and then based on that, the shares were ranked in ten groups. Thus, the most expensive stock (lowest ratio of book value to market value) was in the first group and the cheapest stock (the highest ratio of book value to market value) was in the tenth group.

To create portfolio in year $t$, mentioned ratios were calculated at the end of year $t$ - 1 and companies were arranged independently based on mentioned BM. Shares of companies that member of the set considered 30 percent higher than ratio of $\mathrm{BM}$ as a valuable portfolio and

\footnotetext{
${ }^{1}$ Small Minus Big

${ }^{2}$ High Book to Market Minus Low Book To Market

${ }^{3}$ The book value of common shares is equal to total ofshareholderssalarythat belongs to common stock and for calculating it, the dividing sum of salary belong to ordinary shareholders on the number of common shares of shareholders used.

The book value of an ordinary share $=\frac{\text { salary of ordinary shareholders }}{\text { The number of common shares }}$
} 
shares of companies that member of the set considered 30 percent lower than ratio of $\mathrm{BM}$ as a And shares 30 percent lower than a member of the BMP were considered as a growth portfolio. Then the monthly efficiency of value and growth portfolios were calculated for the year $\mathrm{t}$.

Results of efficiency for ten portfolios that have been calculated and obtained from stock efficiency of companies in the short and long termby comparing the purchase and maintenance methods and the moving average over the study period, has been shown in Table 2.

Table 2. Comparison of the moving average method and the purchase and maintenance method in the short-term and long-term

\begin{tabular}{|c|c|c|}
\hline \multicolumn{3}{|c|}{ the short-term } \\
\hline Portfolios & $\begin{array}{c}\text { purchase and maintenance } \\
\text { method }\end{array}$ & moving average method \\
\hline 1 & 0.25246396 & 0.144619268 \\
\hline 2 & 0.025321417 & 0.192135237 \\
\hline 3 & -0.190071071 & 0.211277263 \\
\hline 4 & 0.208490643 & 0.03091691 \\
\hline 5 & -0.128157647 & 0.136475071 \\
\hline 6 & 0.084218184 & 0.056434376 \\
\hline 7 & 0.002812106 & 0.0644777535 \\
\hline 8 & 0.413324993 & 0.08313538 \\
\hline 9 & 0.250598547 & 0.108975565 \\
\hline
\end{tabular}

\begin{tabular}{|c|c|c|}
\hline \multicolumn{3}{|c|}{ long-term } \\
\hline Portfolios & $\begin{array}{c}\text { purchase and maintenance } \\
\text { method }\end{array}$ & moving average method \\
\hline 1 & 0.345644143 & 0.136798876 \\
\hline 2 & 0.31025302 & 0.160895255 \\
\hline 3 & 0.004165632 & 0.149865509 \\
\hline
\end{tabular}




\begin{tabular}{|l|l|l|}
\hline 4 & 0.268125431 & 0.158967774 \\
\hline 5 & -0.04450758 & 0.269515275 \\
\hline 6 & 0.347263828 & 0.123049546 \\
\hline 7 & 0.605571176 & 0.124852141 \\
\hline 8 & 0.468604022 & 0.168388047 \\
\hline 9 & 0.487901111 & 0.148430805 \\
\hline 10 & 0.631515017 & 0.239237702 \\
\hline
\end{tabular}

Table 3: provides statistics about the variables to use them for selecting the tests and methods of the hypotheses.

Table 3. Descriptive statistics research variables

\begin{tabular}{|c|c|c|c|c|}
\hline & $\begin{array}{c}\text { The average of } \\
\text { purchase and maintenance } \\
\text { methodefficiency }\end{array}$ & $\begin{array}{c}\text { The average of } \\
\text { moving average } \\
\text { method efficiency } \\
\text { one year } \\
\text { efficiency for } \\
\text { purchase and } \\
\text { maintenance } \\
\text { method }\end{array}$ & $\begin{array}{c}\text { The average of } \\
\text { The average of } \\
\text { one year } \\
\text { efficiency for } \\
\text { moving average } \\
\text { method }\end{array}$ \\
\hline Average & 0.3424 & 0.1680 & 0.0948 & $\mathbf{0 . 1 1 6 1 1}$ \\
\hline Variance & 0.051 & 0.002 & 0.035 & $\mathbf{0 . 0 0 3}$ \\
\hline Skewness & -0.596 & 1.460 & 0.130 & $\mathbf{0 . 2 2 9}$ \\
\hline Elongation & -0.338 & 1.259 & -0.592 & $\mathbf{- 0 . 8 3 9}$ \\
\hline
\end{tabular}

\section{The test for normality of the data}

Table 4. Kolmogorov-Smirnov test for purchase and maintenance method

\begin{tabular}{|c|c|c|c|c|}
\hline Period-average & Test statistics & $\begin{array}{c}\text { The significance } \\
\text { level }\end{array}$ & $\begin{array}{c}\text { The level of } \\
\text { error }\end{array}$ & $\begin{array}{c}\text { Normality of the } \\
\text { data }\end{array}$ \\
\hline short term & 0.542 & 0.931 & 0.05 & Acceptance \\
\hline Long term & 0.459 & 0.984 & 0.05 & Acceptance \\
\hline
\end{tabular}


Table 5. Kolmogorov-Smirnov test for moving average method

\begin{tabular}{|c|c|c|c|c|}
\hline Period-average & Test statistics & $\begin{array}{c}\text { The significance } \\
\text { level }\end{array}$ & $\begin{array}{c}\text { The level of } \\
\text { error }\end{array}$ & $\begin{array}{c}\text { Normality of the } \\
\text { data }\end{array}$ \\
\hline short term & 0.359 & 1 & 0.05 & Acceptance \\
\hline Long term & 0.939 & 0.342 & 0.05 & Acceptance \\
\hline
\end{tabular}

Regarding to table 4 and 5 can be seen that the data on the purchase and maintenance method and the method of moving averages, are normal.

\section{Data variance test}

First, for testing the average equality of two communities should check that whether the variances of two populations are equal or not. In other words, the test for equality of variances is prior to the test of average equality.

Statistical hypothesis test for equality of variance of two populations as follows:

Table 6. Results of the test for equality of variance

\begin{tabular}{|c|c|c|}
\hline \multicolumn{2}{|c|}{ Levin test for equality of variance } \\
\hline Significant & & $\mathrm{F}$ \\
\hline 0.011 & & 8.093 \\
\hline
\end{tabular}

Significant was related to Levin test that equal to 0.011and is smaller than the significance level of $5 \%$, thus the equality of variances is rejected.

Table 7. Results of the test for equality of variance

\begin{tabular}{|c|c|c|}
\hline \multicolumn{2}{|c|}{ Levin test for equality of variance } \\
\cline { 1 - 1 } Significant & & $\mathrm{F}$ \\
\cline { 1 - 1 } 0.006 & & 9.714 \\
\hline
\end{tabular}

Significant was related to Levin test that equal to 0.006 and is smaller than the significance level of $5 \%$, thus the equality of variances is rejected.

\section{Comparison test of averages}

The results of equality average test of two communities for both equality and inequality variance is as follows: 
Table 8. Results of average test of main model

\begin{tabular}{|c|c|c|c|c|c|c|}
\hline \multicolumn{2}{|c|}{ Confidence interval 95\% } & Significant & $\begin{array}{c}\text { Degrees of } \\
\text { freedom }\end{array}$ & $T$ & & \\
\hline upper limit & lower limit & 0.028 & 18 & 2.385 & $\begin{array}{c}\text { Equality of } \\
\text { variance }\end{array}$ & $\begin{array}{c}\text { Average of } \\
\text { efficiency }\end{array}$ \\
\hline $\mathbf{0 . 3 2 8 1 5}$ & 0.02074 & 0.039 & 9.822 & 2.835 & $\begin{array}{c}\text { Unequal } \\
\text { variance }\end{array}$ & \\
\hline $\mathbf{0 . 3 3 7 8 6}$ & 0.01104 & & & & & \\
\hline
\end{tabular}

Since equal variance assume was denied. So assumption of non-equality considered for the conclusion about accepting or rejecting the hypotheses. Significance of Average equity test by assuming of unequal variances is less than $5 \%$,then zero hypotheses is rejected and claims of inequality average of efficiency of purchase and maintenance method portfolio and the moving average method portfolio will be accepted in error level of 5 percent.Considering that the confidence interval for the difference of average between the two groups is positive therefore average difference between the two groups is greater than zero. From this, we can conclude that the first population average namely, the average of purchase and maintenance method portfolio return is greater than the moving average method.

Hypothesis Statistical tests: Average portfolio efficiency for one-year of purchase and maintenance method in the short period of time is more than the moving average method. The test results of average equity of the two communities for both equity and unequal variance is as follows:

Table 9. Results of average test

\begin{tabular}{|c|c|c|c|c|c|c|}
\hline \multicolumn{2}{|c|}{ Confidence interval 95\% } & Significant & $\begin{array}{c}\text { Degrees of } \\
\text { freedom }\end{array}$ & $T$ & & \\
\hline upper limit & lower limit & 0.736 & 18 & -0.343 & $\begin{array}{c}\text { Equality of } \\
\text { variance }\end{array}$ & $\begin{array}{c}\text { Average of } \\
\text { efficiency }\end{array}$ \\
\hline $\mathbf{0 . 1 0 8 8}$ & -0.1513 & 0.738 & 10.757 & -0.343 & $\begin{array}{c}\text { Unequal } \\
\text { variance }\end{array}$ & \\
\hline $\mathbf{0 . 1 1 5 4}$ & -0.1578 & & & & & \\
\hline
\end{tabular}


Since equal variance assume was denied.So assumption of non-equality considered for the conclusion about accepting or rejecting the hypotheses. Significance of Average equity test by assuming of unequal variances is more than $5 \%$, then the zero hypotheses is accepting and claims of inequality average of efficiency of purchase and maintenance method portfolio and the moving average method portfolio will be rejected in error level of 5 percent.

Hypothesis Statistical tests: The average efficiency on a portfolio of short-term and long-term of purchase and maintenance method has significant difference.

To examine the relationship, (correlation) of two variables, statistical hypothesis can be defined as follows:

$\mathrm{H}_{0}=$ There was no significant correlation between the two variables.

$\mathrm{H}_{1}=$ There was a significant correlation between the two variables.

Table 10. Correlation test

\begin{tabular}{|c|c|c|}
\hline Test & Correlation & significance \\
\hline paired Compare & 0.68 & 0.028 \\
\hline
\end{tabular}

Due to the significance of the test, the zero hypothesis is rejected. In result, there was a significant correlation between the two variables. However, in order to test the claim that the average of efficiency on a portfolio of short-term and long-term of purchase and maintenance method has no significant difference, paired comparison test is used. The results are as follows:

Table 11. Results of paired test

\begin{tabular}{|c|c|c|c|c|c|}
\hline Test & average & $\begin{array}{c}\text { Standard } \\
\text { deviation }\end{array}$ & Statistics & $\begin{array}{c}\text { Degrees of } \\
\text { freedom }\end{array}$ & significance \\
\hline $\begin{array}{c}\text { paired } \\
\text { comparison }\end{array}$ & -0.24755 & 0.16709 & -4.685 & 9 & 0.001 \\
\hline
\end{tabular}

Significance of test is smaller than 5\%, therefore the zero hypothesis is rejected and the opposite hypothesis is accepted.In other words, there is a significant difference between the average efficiency of the portfolio in short-term and long-term.

\section{Estimation of Fama and French model by using EViews software}


In first step by using the EViews software, to avoid spurious regression, unit roots are examined to be viewed that whether the data has unit root or not? (Table 12)

Table 12. Checking the presence or absence of unit root variables.

\begin{tabular}{|c|c|c|c|}
\hline Stationary surface & Possibility & $\begin{array}{c}\text { Generalized statistics } \\
\text { of Dickey Fuller }\end{array}$ & Variable name \\
\hline 0 & 0 & -5.5263 & $\mathrm{R}$ \\
\hline 0 & 0 & -5.5179 & MKT \\
\hline 0 & 0 & -7.0956 & SMB \\
\hline 0 & 0 & -7.1033 & HML \\
\hline
\end{tabular}

$\mathrm{H}_{0}=$ has unit root $\mathrm{H}_{0}$ is rejected(in the Significant confidence level of $5 \%$ and even less unit root is rejected) $\mathrm{H}_{1}=$ does not have any root

As we can see in result, in the Significant confidence level of 5\% and even less unit root is rejected and was confirmed the absence of unit root in them with very high confidence. In other words, the data are stationary and the degree of integration is zero. Therefore, because there is no a spurious regression problem, then you can easily use the OLS method.

Dependent Variable: $\mathrm{R}$

Method: Least Squares

Date:09/21/15 Time:11:30

Sample:1387M10 1393M10

Included observations: 73 
Table 13. Estimated regression model of Fama and French

\begin{tabular}{|l|l|l|l|l|}
\hline Variable & Coefficient & Std. Error & t-Statistic & Prob. \\
\hline C & 0.153860 & 0.003678 & 41.82911 & 0.0000 \\
\hline MKT & 0.999267 & 0.000543 & 1838.778 & 0.0000 \\
\hline HML & 0.021140 & 0.010579 & 1.998252 & 0.0496 \\
\hline SMB & 0.010027 & 0.008898 & 1.126849 & 0.2637 \\
\hline R-squared & 0.999984 & $\begin{array}{l}\text { Mean } \\
\text { dependent var }\end{array}$ & 3.040915 & \\
\hline $\begin{array}{l}\text { Adjusted R- } \\
\text { squared }\end{array}$ & 0.999984 & S.D. dependent var & 7.091415 & \\
\hline $\begin{array}{l}\text { S.E. of } \\
\text { regression }\end{array}$ & 0.028631 & Akaike info criterion & -4.215431 & \\
\hline $\begin{array}{l}\text { Sum squared } \\
\text { resid }\end{array}$ & 0.056561 & Schwarz criterion & -4.089926 & \\
\hline Log likelihood & 157.8632 & Hannan-Quinn criter. & -4.165415 & \\
\hline F-statistic & 1472323. & Durbin-Watson stat & 0.329968 & \\
\hline Prob(F-statistic) & 0.000000 & nat & & \\
\hline
\end{tabular}

In following according to Table 13, reviews of estimation of the Fama and French model regression was done, that in this methodR with 0.99 was obtained well; Which represents the explanation of 33 percentage of the rate of anticipated changes efficiency of the moving average method. The only problem obtained,was the low Watson camera in the results.For this reason, it can be seen that there is a positive correlation between the disturbing elements and to determine the correlation you shoulduse Log correlation charts.So in continue Correlogram chart or graphic correlation disturbing elements drawn and examined to determine the degree of correlation. 
Table 14. Evaluation of disturbing elements with the use of correlograming

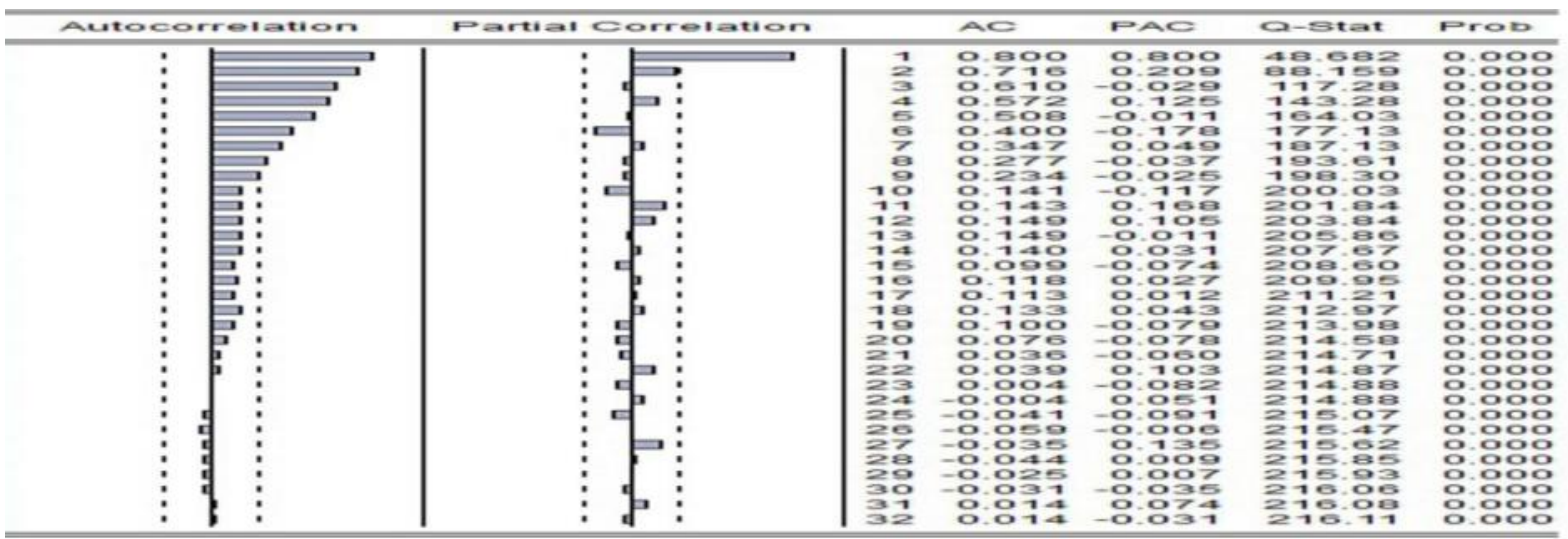

The result that has been observed from Correlograming is that; because in partial correlation, PAC has been in the critical area as well as the AC is exponentially decreasing;thus, disturbing components have the process of $\mathrm{AR}(1)$. Dou to this reason in the subsequent regression, AR was entered by order of 1 and thereby, all variables were significant (Table $15)$.

Dependent Variable: $\mathrm{R}$

Method: Least Squares

Date:09/16/15 Time: 12:41

Sample (adjusted): 1387M11 1393M10

Included observations: 72 after adjustments

Convergence achieved after 7 iterations 
Table 15. Estimated regression of Fama and French model with respect to the $A R_{(1)}$ to fix the autocorrelation problem

\begin{tabular}{|c|c|c|c|c|}
\hline Variable & Coefficient & Std. Error & t-Statistic & Prob. \\
\hline $\mathrm{C}$ & 0.403702 & 1.523822 & 0.264927 & 0.7919 \\
\hline MKT & 0.999894 & 0.000131 & 7646.227 & 0.0000 \\
\hline HML & -0.006072 & 0.002220 & -2.735589 & 0.0080 \\
\hline SMB & -0.004974 & 0.001799 & -2.764364 & 0.0074 \\
\hline $\mathrm{AR}_{(1)}$ & 0.994316 & 0.034054 & 29.19821 & 0.0000 \\
\hline R-squared & 0.999999 & $\begin{array}{l}\text { Mean dependent } \\
\text { var }\end{array}$ & \multicolumn{2}{|c|}{3.072779} \\
\hline Adjusted R-squared & 0.999999 & $\begin{array}{l}\text { S.D. dependent } \\
\text { var }\end{array}$ & \multicolumn{2}{|c|}{7.135915} \\
\hline S.E. of regression & 0.008355 & $\begin{array}{l}\text { Akaike info } \\
\text { criterion }\end{array}$ & \multicolumn{2}{|c|}{-6.665060} \\
\hline Sum squared resid & 0.004677 & $\begin{array}{l}\text { Schwarz } \\
\text { criterion }\end{array}$ & \multicolumn{2}{|c|}{-6.506958} \\
\hline Log likelihood & 244.9421 & $\begin{array}{l}\text { Hannan-Quinn } \\
\text { criter. }\end{array}$ & \multicolumn{2}{|c|}{-6.602119} \\
\hline F-statistic & 12948847 & $\begin{array}{l}\text { Durbin-Watson } \\
\text { stat }\end{array}$ & \multicolumn{2}{|c|}{1.880339} \\
\hline Prob(F-statistic) & 0.000000 & & & \\
\hline Inverted AR Roots & .99 & & & \\
\hline
\end{tabular}

Then, the components of disturbing were investigated again in new model, it was observed that all of them was entered to formed area of PAC and AC and the amount of data ofWatson camera raised and there is no longer a problem of autocorrelation. 
Table 16. Evaluation of disturbing elements with the use ofcorrelograming after entering the $\mathrm{AR}_{(1)}$

\begin{tabular}{|c|c|c|c|c|c|c|}
\hline Autocorrelation & Partial Correlation & & $A C$ & PAC & a-stat & Prob \\
\hline $\begin{array}{l}\vdots \\
\vdots \\
\vdots \\
\vdots \\
\vdots \\
\vdots \\
\vdots \\
\vdots \\
\vdots \\
\vdots \\
\vdots\end{array}$ & $: 4:$ & $\begin{array}{r}1 \\
2 \\
3 \\
4 \\
5 \\
6 \\
7 \\
8 \\
9 \\
10 \\
11 \\
12 \\
13 \\
14 \\
15 \\
16 \\
17 \\
18 \\
19 \\
20 \\
21 \\
22 \\
23 \\
24 \\
25 \\
26 \\
27 \\
28 \\
29 \\
30 \\
31 \\
32\end{array}$ & $\begin{array}{r}0.060 \\
-0.037 \\
-0.034 \\
-0.001 \\
-0.069 \\
0.021 \\
-0.057 \\
-0.050 \\
0.016 \\
0.048 \\
-0.058 \\
0.021 \\
-0.001 \\
-0.036 \\
-0.042 \\
-0.017 \\
-0.055 \\
-0.057 \\
-0.015 \\
-0.006 \\
-0.017 \\
-0.050 \\
0.059 \\
-0.009 \\
0.017 \\
-0.007 \\
-0.067 \\
0.011 \\
-0.065 \\
0.023\end{array}$ & 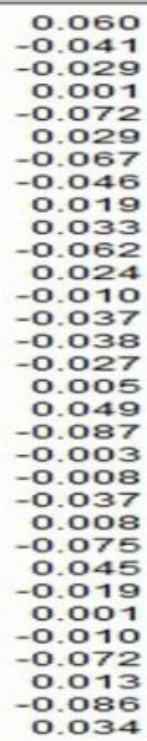 & $\begin{array}{l}0.2683 \\
0.3733 \\
0.4608 \\
0.4610 \\
0.8443 \\
0.8785 \\
1.1474 \\
1.3568 \\
1.5783 \\
1.8746 \\
1.9100 \\
1.9101 \\
2.0260 \\
2.1927 \\
2.2202 \\
2.2225 \\
2.5450 \\
2.9830 \\
3.0046 \\
3.0079 \\
3.0379 \\
3.0379 \\
3.3928 \\
3.4904 \\
3.4915 \\
3.5276 \\
3.5335 \\
4.0835 \\
4.0982 \\
4.6115\end{array}$ & $\begin{array}{l}0.604 \\
0.830 \\
0.927 \\
0.977 \\
0.974 \\
0.990 \\
0.992 \\
0.995 \\
0.998 \\
0.999 \\
1.000 \\
1.000 \\
1.000 \\
1.000 \\
1.000 \\
1.000 \\
1.000 \\
1.000 \\
1.000 \\
1.000 \\
1.000 \\
1.000 \\
1.000 \\
1.0000 \\
1.000 \\
1.000 \\
1.000\end{array}$ \\
\hline
\end{tabular}

Thus, because of freedom from any kind of problem, this new model is interpreted:In other words, the amount of risk premium price, size and market value is exist, it can be predicted that if 1 unit of studied stock efficiency is greater than bonds efficiency of market, 0.99 will increase the efficiency of the market. Also, because the risk premium size ${ }^{1}$ and value ${ }^{2}$ have a negative value; they have the negative effect on forecasting the efficiency of shares $(50 \mathrm{~s}$ examined in this study).

\section{CONCLUSION}

According to the information provided in this study and its findings can be concluded that because stock prices always move to its value, there are ways to predict prices in the future that technical analysis is the best and most accurate tools. And also proved that at the moment Fama and French three-factor model is one of the best models for predicting the minimum error.And the moving average method has high signaling capability.

Also, according to the results of the assumptions it was concluded that the average efficiency on a portfolio of short-term and long-term of purchase and maintenance method has

\footnotetext{
${ }^{1}$ unit of anticipatedStock efficiency has decreased.

${ }^{2}$ The size of each unit increase in the value, to -0.006 unit efficiency has decreased.
} 
significant difference and there is a significant relationship between stock efficiency and efficiency of bonds. As if 1 unit of studied stock efficiency is greater than bonds efficiency of market, 0.99 will increase the efficiency of the market.

\section{Suggestions}

With regard to the findings and conclusions of research can be recommended to investors and entities that just not rely to cause systemic risk as an explanatory variable of efficiency when buying stocks and analysis of the relationship between risks and return and use different methods such as models of technical analysis in their decisions. Because taking into account the factors such as size, liquidity of the stock and the ratio of book value to market value can also improve their decision-making power. Establishment a new risk and stock efficiency on the one hand and its liquidity on the other hand is the art of stock portfolio managers that can be able to improve by using conducted research in the capital market of this area. This study also suggested the formation of a portfolio with zero cost with by purchasing the highest portfolio book value at market prices(BM) and sales the lowest portfolio's book value (BM) by signals issued by Moving Average.However, in applying the results of this kind of research requires that the issue of market efficiency should be considered.In this sense, the relationship between different variables in the market may vary due to the market performance.

\section{REFERENCES}

[1] Ahmadpur A, Rasaiian A, The relationship between risk measures and the differences of price of purchase and sell shares on the Tehran Stock Exchange, Quarterly of review of accounting and auditing, 2006, 46.

[2] Ahmadpur A, The effect of company size and the ratio of book value to market value on stock efficiency, Journal of Economic Research, Tehran, 2007, 79.

[3] Aghabeighi S, Evaluation of market factors, firm size and book value to market value with stock efficiency of companies that accepted in Tehran Stock Exchange, Master of Financial Management, Shahid Beheshti University, 2005.

[4] Bagherzadeh S, Factors affecting stock returns in the Tehran Stock Exchange. Journal of Financial Research, Tehran, spring and summer of 2005, 19: 25-64.

[5] Bayazidi A, Ouladi B, Abasi N, Afreydon Kh, "statistical analysis" Book with MINITAB, Tehran, Abed publishing, 2012. 
[6] Brovary F, Jabbarzadeh S, Mohammadi B, Alipour A, Concepts and principles of investment in the stock market, Urmia, Islamic Azad University, 2013.

[7] Hesami A, Analytical review of the relationship between accounting profit and stock efficiency of companies listed in the Tehran Stock Exchange, Master's thesis, Shahid Beheshti University, Faculty of Administrative Sciences, 1999.

[8] Khajavi Sh, Nazemi A, Examine the relationship between profit quality and stock efficiency with an emphasis on the role of accrual items on the stock exchange, Tehran, Review of Accounting and Auditing, 2005, 37.

[9] Robat M, Compare the performance of the capital asset pricing model (CAPM) with Fama and French three-factor model to predict the expected efficiency on the Tehran Stock Exchange,Master of Accountancy, University of Al Zahra, 2007.

[10] Rasaiian A, Hosseini V, the relation between accrual items quality and cost of invest in Iran, accounting and audit investigations,2008, 53.

[11] Dastgir M, Rastegar M, The relationship between profit quality (profit stability) magnitude of accruals and stock returns with accrual items quality, the Financial Accounting Research,2011,3(1).

[12] Samii Sh, Shabanali M, Anticipated price in the stock market using technical analysis, Fourth Edition, Tehran, 2013.

[13] Suri A, "New Theory of portfolios and analysis of investment", Tehran, Monetary and Banking Research Institute of the Central Bank of the Islamic Republic of Iran, 2012.

[14] Taremi M, Fama and French three-factor model test at the Tehran Stock Exchange to predict stock returns, Master of Accounting, University of Al Zahra, 2006.

[15] Arab M, Mashayekhi B, Rafeie A, Cash flows and accrual information content in the Iranian capital, accounting and audit review, 2006, 43.

[16] Farahani k, Langroodi R, Technical Analysis in the capital markets, Tehran, Chalesh publishing, 2005

[17] Ghaemi M.H, Jamal, A, Dehbozorgi S, Quality of earnings and stock efficiency, the review of accounting and auditing, 2008, 52.

[18] Kurdestani Gh, Roudneshin H, Evaluation of the components of cash and accrual accounting the company's market value, the accounting and auditing review, 2006, 45.

[19] Makarem A, Assess and compare the ability investment asset pricing model (CAPM) and Fama and French three-factor model to explain the volatility of stock efficiency of companies listed in Tehran Stock Exchange. Master of Financial Management, Tarbiat Modarres University, 2007. 
[20] Brock W, Lakonishok J, LeBaron B, Simple technical trading rules and the stochastic properties of stock returns. Journal of Finance, 1992, 47: 1731-1764.

[21] Brown D.P, Jennings R.H.,. On technical analysis. Review of Financial Studies 2, 1989: $527-551$.

[22] Lo A.W., Mamaysky H., Wang J, Foundations of technical analysis: computational algorithms, statistical inference, and empirical implementation. Journal of Finance, 2000, 55: $1705-1770$.

[23] Neely C.J, Rapach D.E, Tu J, Zhou G, Forecasting the equity risk premium: the role of technical indicators. Working paper. Washington University, St. Louis, 2011.

[24] Kuan-Cheng ko \& Shinn-juh,Lin \& Hsiang-Ju Su \& Hsing-Hua, Chang,(2013), Value Investing And Technical Analysis In Taiwan Stock Market , Pacific-Basin Finance Journal 26 2014: $14-36$.

[25] Han Y, Yang K, Zhou G, A new anomaly: the cross-sectional profitability of technical analysis. Journal of Financial and Quantitative Analysis (forthcoming), 2013.

Rouwenhorst K.G,. Local return factors and turnover in emerging stock markets. Journal of Finance, 1999, 54: 1439-1464.

[26] Mukherji S, Dhatt M.S, Kim, Y.H,. A fundamental analysis of Korean stock returns. Financial Analysts Journal 1997 54: 75-80.

Chen N.F, Zhang, F, Risk and return of value stocks. Journal of Business, 1998, 71: 501-535. [27] Chui A.C.W, Wei K.C.J, Book-to-market, firm size, and the turn-of-the-year effect: evidence from Pacific-Basin emerging markets. Pacific-Basin Finance Journal, 1998，6: 275293.

[28] Ding D.K, Chua J.L, Fetherston, T.A,. The performance of value and growth portfolios in East Asia before the Asian financial crisis. Pacific-Basin Finance Journal, 2005, 13: 185199.

[29] Core J, Guay W, Verdi R, Is accruals quality a priced risk factor. Journal of Accounting and Economics, 2008, 46: 2-22.

[30] Francis J, LaFond R, Olsson P, Schipper K, "The market pricing of accruals quality“.Journal of Accounting and Economics, 2005, 39: 295-327.

[31] Fama E, MacBeth J. "Risk, return, and equilibrium: empirical tests“. Journal of Political Economy, 1973, 81: 607-636.

[32] Fama E.F, French K.R, The cross section of expected stock returns. Journal of Finance, 1992, 47: 427-466. 
[33] Fama E.F, French, K.R, Common risk factors in the returns on stocks and bonds. Journal of Financial Economics, 1993, 33: 3-56.

[34] Fama E.F, French K.R, Multifactor explanations of asset pricing anomalies. Journal of Finance, 1996, 51: 55-84.

[35] Fama E.F, French K.R, Value versus growth: the international evidence. Journal of Finance, 1998, 53: 1975-1999.

[36] Ahmadpour A. and Resaeian A. Relationship between Risk Criteria's and Bid- Ask Spread in Tehran Security Exchange, Accounting and Audit Researches, 1385: 37-60, (in Persian).

[37] Yahyazadehfar M. and Khoramdin J. Role of Liquidity Factors and Illiquidity Risk on Surplus Stock Return in Tehran Security Exchange, Accounting and Audit Researches, 1387, 53: 101-118, (in Persian).

[38] Francis J, LaFond R, Olsson P, Schipper K. "The market pricing of accruals quality“.Journal of Accounting and Economics, 2005, 39: 295-327.

[39] Chan K.L, Chan N, Jegadeesh J. "Earnings quality and stock returns", Journal of business, forthcoming. 2006

[40] Mouselli, Sulaiman. Jaafar, Aziz.(2009). Is Accruals Quality Priced in UK?. Www.ssrn.com. Working paper.

[44] Kim, Dongcheol. Qi, Yaxuan. (2009)."Accruals Quality, Stock Returns, and Macroeconomic Conditions". www.ssrn.com. Working paper.

[45] Allen D. E. and Cleary "Determinates of the Cross-section of stock returns in the Malaysian stock" . market international review of financial Analysis, 1998, 7(5): 253- 275.

[46] Bartholdy, jan \& paula Pear, (2002) “Estimation of expected return: CAPM vs Fama and French", Workin Paper http://ssrn.com/abstract=350100 or DOI: 10.2139/ssrn.350100.

[47] Sehgal, Sanji and Garhyan, Anurag, The Singificance of Technical-Trading rules Profits in the Forign Exchange Market: A bootstap approach, Journal of International Money and Finance, 2002, 12(5): 451-474.

\section{How to cite this article:}

Sokhanvar M, Farman A. Reduce the risk of stock trading by using technical analysis in iran's stock market. J. Fundam. Appl. Sci., 2016, 8(2S), 1238-1256. 